\title{
Uluslararası Ekonominin Covid-19'a Karşı Piyasalardaki Durumunun Yatırımlar Perspektifinden İncelenmesi
}

\section{Investigation of the International Economy Against Covid-19 in the Markets from the Investment Perspective}

\author{
Suna ŞAHİN ${ }^{1} *$ \& Avni Aykut AKDA $\breve{G}^{2}$
}

Geliş / Received: 15/09/2021

Revize / Revised: 19/11/2021

Kabul / Accepted: 26/11/2021

\begin{abstract}
ÖZ
2020 yılının mart ayında başlayan Covid-19 salgın krizi gelișmiș ve gelişmekte olan birçok ülkeyi sert bir şekilde vurmuş ve dünya genelinde ortaya konulan sürdürülebilir kalkınma hedeflerinin gerçekleşmemesine neden olmuştur. Bu durum özellikle gelişmekte olan ülkelerdeki kalkınma hedeflerine ulaşmada engel oluşturmuştur. Covid-19 salgın krizi ülke ekonomilerinin arz ve taleplerini değişime uğratmıştır. Bu durum ise özellikle finansal piyasalarda krizler yaşanmasına sebebiyet vermiştir. Gelişmiş ülkeler tarafından sağlanan yardım, zayıf ekonomileri olan ve özellikle uluslararası sermaye piyasalarına erişimi olmayan ülkeler için yetersiz düzeydedir. Ancak hali hazırda yardım etmesi gereken gelişmiş ülkelerin çoğu, ekonomik büyüme, üretim çıktısı, istihdam oranı, mali durum ve borç miktarı gibi kötüleşen makroekonomik koşullarla karşı karşıya kalmıştır. Global ekonomilerin etkileşiminin hızla arttığı bir dönemde gelişmekte olan ve az gelişmiş ülkeler yabancı kaynakları ülkelerine çekmek için çabalarını artırmaktadırlar. Büyümeleri için gerekli olan kaynaklar doğrudan yabancı yatırımlar ve sıcak para da diyebileceğimiz finansal piyasalara olan yatırımlardan oluşmaktadır. Bu ülkeler yatırımları çekmek isteseler de özellikle az gelişmiş olan ülkelerin finansal piyasaları çok az gelişmiş olduğu için çekebilecekleri yatırımlar sadece doğrudan yatırımlar şeklinde olacaktır. Burada da o ülkelerde rekabet avantajı, ucuz hammadde, ucuz iş gücü, hukuk altyapısı, güvenlik gibi çok çeşitli faktörler devreye girmekte ve istenilen yatırım tutarlarına ulaşmak mümkün olmamaktadır. Yapılan bu çalışmada, uluslararası yatırımlarda ülkelerin politik, ekonomik ve yerel faktörlerinin önemi dışında böyle bir salgın sürecinde uluslararası sermaye yatırımlarının hem dünya ülkelerinin hem de Türkiye'nin finansal tablolarına olan etkisi değerlendirilmiştir. Çalışmada salgın sürecine ilişkin durum yazarlar tarafından hesaplanan veriler ışığında anlatılmıştır. Sonuç olarak salgın ülkelere sadece sağlık alanında değil ekonomik anlamda da derin sarsıntılar yaşatmıştır. Ülkeler hem kısa hemde uzun vadeli ekonomi politikaları oluşturmalı ve küresel sistem içerisindeki karşılıklı etkileşimleride dikkate alarak bu süreci en az zararla, kontrollü bir şekilde ilerletmeye çalışmalıdır. Krizleri fırsata çevirmeyi başaran ülkelerin süreçten karlı çıkmasıda muhtemeldir.
\end{abstract}

Anahtar Kelimeler- Uluslararası Sermaye Yatırımları, Finansal Piyasalar, Küresel Salgın, Uluslararası Ekonomi.

\begin{abstract}
The Covid-19 epidemic crisis, which started in March 2020, hit many developed and developing countries hard and prevented the achievement of the sustainable development goals. This situation has created an obstacle especially for the developing countries. The Covid-19 epidemic crisis has changed the supply and demand balances of the world economies. This situation caused crises especially in financial markets. Aid provided by developed countries is insufficient, especially for countries with weak economies and insufficient access to international capital markets. Most of the developed countries that should have helped already have faced worsening macroeconomic conditions such as economic growth, production output, employment rate, finances and amount
\end{abstract}

\footnotetext{
1* Sorumlu Yazar, Dr. Öğr. Üyesi, İstanbul Yeni Yüzyıl Üniversitesi, İktisadi ve İdari Bilimler Fakültesi, Uluslararası Ticaret ve Lojistik Bölümü, suna.sahin@yeniyuzyil.edu.tr, (https://orcid.org/0000-0002-8241-739X) 2 Dr. Öğr. Üyesi, İstanbul Yeni Yüzyıl Üniversitesi, İktisadi ve İdari Bilimler Fakültesi, İşletme Bölümü, aykut.akdag@yeniyuzyil.edu.tr, (https://orcid.org/0000-0002-2600-0784)
} 
of debt. At a time when the interaction of global economies is increasing rapidly, developing and underdeveloped countries are increasing their efforts to attract foreign resources to their countries. Although these countries want to attract investments, the investments they can attract will only be in the form of direct investments, especially since the financial markets of underdeveloped countries are very underdeveloped. Here, too, various factors such as competitive advantage, low cost raw materials, low wage labor, legal infrastructure and security come into play in those countries, and it is not possible to reach the minimum targeted investment goals. In this study, apart from the importance of the political, economic and local factors of the countries in international investments, the effect of international capital investments on the financial tables of both the world countries and Turkey during such an epidemic was evaluated. In the study, the situation regarding the epidemic process was explained in the light of the data calculated by the authors. As a result, the epidemic has caused deep shocks to the countries not only in the field of health but also in the economic sense. Countries should create both short-term and long-term economic policies and try to advance this process in a controlled manner with the least damage, taking into account the mutual interactions within the global system. It is likely that countries that have succeeded in turning crises into opportunities will profit from the process.

\section{Keywords- International Capital Investments, Financial Markets, Global Pandemic, International Economy.}

\section{GíRiş}

Dünya Sağlık Örgütü, 11 Mart 2020 tarihinde tıp terminolojisinde kullanılan Pandemi terimini kullanarak dünyayı saran ve insanların sağlıklarını bozan bulaşıcı hastalı̆̆ı ilan etmiştir (Türkiye Bilimler Akademisi, 2020:20). Bu salgın dünya ülkelerini etkileyerek yeni bir dünya düzenine doğru gidilmesine sebebiyet vermiş̧tir. Ülkeler salgına yakalanmama ya da salgını en az hasarla atlatmak adına koruyucu önlemler almaya çalışmış olsalar da salgın birçok alanda etkisini hızlıca göstermiştir. Dünya ekonomilerini çöküş seviyesine getirmiş ve tüketim ile üretim kalıplarının değişmesine, istihdam oranlarının olumsuz yönde etkilenmesine neden olmuştur. Salgın nedeniyle ortaya çıkan işsizlik durumunu düzeltebilmek için birçok ülke harcama artırıcı para politikaları uygulamışlardır (Mishra, 2020: 9).

Covid-19'un, 1930'ların Büyük Buhranından bu yana en derin küresel kriz olduğu göz önüne alındığında, kalkınma yardımı üzerinde önceki kriz çalışmalarında önerilenden çok daha güçlü bir etkiye sahip olması muhtemeldir. Yardım etmesi gereken gelişmiş ülkelerin azgelişmiş ülkelerin bütçelerini korumak için çaba göstereceklerine dair söz vermelerine rağmen, 2020'nin ilk beş ayı endekslerine bakıldığında Uluslararası Yardım fonlarına bildirilen ikili yardım taahhütleri 2019'un aynı dönemine göre yaklaşık yüzde 30 daha düşük durumdadır. Dünya Bankası, salgın sonucunda 2020 yılında 40 ila 60 milyon insanın aşırı yoksulluğa sürüklenebileceğini ve bunun da 2030 yılına kadar yoksulluğun sona erdirilmesini zorlaştıracağını ön görmektedir.

Gelişmiş ülkeler, pandemi süreci başladı̆̆ı dönemlerde ekonomik veriler ile ilgili krize yanıt olarak uluslararası destek önlemlerini açıkladılar, ancak bu, düşük gelirli ülkelerde toparlanmayı desteklemek ve kriz öncesi finansal piyasaların seviyelerini sürdürmek için yeterli değildir. Bu yardımların yapılamamasının nedenlerinden biri beyan edilen harcamaların bazıları, aşı geliştirmeye yönelik ülke içi harcamalara aktarılmasındandır. Diğer yandan gelişmiş ülkeler tarafından Covid-19 krizine yavaş ve yetersiz yanıt verilmesi, BRICS gibi yükselen güçlerin uluslararası kalkınma yardımı çerçevesinde daha büyük bir rol oynaması için bir fırsat sunmaktadır. BRICS ülkeleri, özellikle Çin ve Rusya, küresel konularda liderlik yapmaya ve uluslararası kalkınma yardımı sağlamaya hazır olduklarını gösterdiler. Örneğin Rusya, dünya çapında 46 ülkeye Covid-19 testleri, koruyucu ve tıbbi ekipman, ilaç, sağlık personeli dağıtmış ve fon yönlendirmiştir. Rusya, ikili yardımın yanı sıra Birleşmiş Milletler Kalkınma Programı, Kızılhaç ve Dünya Sağlık Örgütü gibi uluslararası kuruluşlara da ek katkılarda bulunmuştur.

$\mathrm{Bu}$ çalışmada küresel salgın Covid-19 nedeniyle gelişmekte olan ülkelerin yatırım ve sermaye piyasalarındaki durumu ele alınmıştır. Çalışmanın bu alanlarda araştırma yapan diğer alanlardaki çalışmalar içinde kaynak oluşturacağı düşünülmektedir. Covid-19 ülkelerin hem dış ticaret politikalarını hem de finans akışlarını etkilemiştir. Pandemi sürecinde ülkelerin dış ticaret politikaları hızlıca değişim göstermeye başlamıştır. Bu husus her ülkenin salgının etkisinden daha az etkilenmek adına önlemler almasına sebebiyet vermiştir. Ülkeler kendi ekonomik konjonktür ve salgının ülkelerindeki durumuna göre önlemler almaya çalışmışlardır. Merkez Bankaları para politikaları ile çeşitli uygulamalar yaparak ve maliye politikalarını kullanarak salgının ülke ekonomisi üzerindeki olumsuz etkilerini bertaraf etmeye çalışmaktadır. Birçok üretim kanalının üretiminin durma noktasına 
gelmesi hatta birçok sektörde durması istihdam düzeyini etkilemiştir. Bankacıllk sektörü ve reel sektöre likidite sağlanması amacıyla uygulamalar başlatılmak zorunda kalınmıştır. Arz ve talep koşulları göz önüne alındığında salgın sürecinde hem arzın hem de talebin eşanlı düşmesi ekonomik krizin göstergesi olarak da değerlendirilebilir. Üretimin azalmasıyla ortaya çıkan arz şokları ve tüketimlerin değişmesiyle ortaya çıkan talep şokları, ticaret alanında finans sektörüne etki ederek küresel bağlamda bütün ülkelere etki edebilmektedir (Loayza ve Pennings, 2020: 3). Finansal akımların yönü, işgücü piyasalarının durumu, turizm sektörünün seyahat kısıtlamaları nedeniyle durumu gibi konular küresel anlamda birbirine bağlı olan ülkelerin ekonomilerini derinden etkilemektedir (African Union, 2020: 6). Literatürde Temir (2020), Hıdıroğlu (2020), Özer ve Kaba, (2020), Soylu (2020), Güney ve Hopoğlu (2021) çalışmalarında Covid-19'un piyasalar üzerindeki etkilerini değerlendirmişler ve salgının ülke ekonomilerini derinden etkilediğini göstermişlerdir. Sermaye piyasalarında Covid-19 nedeniyle yaşanan negatif durgunluklar neredeyse ülkelerin çoğunun ekonomilerini iflasa sürüklemiştir. Küresel ekonomik kriz olarak görülen Covid-19 gelişen ya da gelişmekte olan ülkelerin resesyon yaşamasına sebep olmuştur.

\section{YATIRIMLARI ETKİLEYEN UNSURLAR}

Uluslararası yatırımların, kaynakların etkin ve verimlilik artışının sağlanması konusunda önemi büyüktür. Gelişmekte olan ülkelerdeki sermaye yetersizliği doğrudan yabancı yatırımları ülkenin kalkınması için zorunlu kılmaktadır (Sabır, 2001: 23). Dolayısıyla özellikle sermaye yetersizliği olan ülkeler için doğrudan yabancı yatırımlar ülkenin rekabet güçlerini artırmakta, ekonomik büyüme hızını yükseltmekte, teknolojinin gelişmesini sağlayarak istihdamını artırmakta, dış ticaret açıklarının azaltılmasında katkı yapmaktadır (Bayraktar, 2003: 2). Doğrudan yabancı yatırımları belirleyen faktörler Birleşmiş Milletler Ticaret ve Kalkınma Konferansı (UNCTAD) 1998 yılında hazırladığı rapora göre; "ekonomik faktörler, yatırım ortamına ait faktörler ve politik faktörler" lerdir (UNCTAD, 1998). Bu faktörlere ilaveten sosyal faktörlerde önemlidir. Sosyal faktörler arasında sağlık, eğitim, altyapı ve sivil özgürlükler önemli bir yer tutmaktadır.

Çok uluslu şirketlerin bir ülkede yatırım yapmasında ülkelerin ekonomik, sosyal göstergeleri büyük önem arz etmektedir. Doğrudan yabancı yatırımlar, özellikle gelişmekte olan ülkeler açısından değerlendirilmesi gereken önemli bir unsur olarak bilinmektedir. Bir ülkenin doğrudan yabancı yatırım performansı gerek yasal düzenlemelerle gerekse siyasi, ekonomik, coğrafik ve kültürel faktörler ile belirlenmektedir (Erdinç ve Aydınbaş, 2020: 14). Döviz kurunun volatilitesindeki değişimler, bürokrasinin ağır işleyişi, yolsuzluk ve rüşvet, piyasasının darlığı gibi konular yatırımların kaçmasına neden olmaktadır. Buna ilaveten doğrudan yabancı yatırımları yolsuzlukların artırdığını öne süren çalışmalarda (Egger ve Winner, 2005; Vial ve Hanoteau, 2010) bulunmaktadır. Çok uluslu şirketlerin birinci amacı kar elde etmek akabinde kendine yeni piyasalar oluşturmak, ölçek ekonomilerinden yararlanmak şeklinde olduğunu belirtebiliriz. Bütün bunlara ilaveten bazen de coğrafi konumu nedeniyle diğer bir değişle ulaşım kolaylığı sağlayacak ülkelerin piyasa büyüklükleri geniş olmasa da örneğin, Hong Kong gibi yabancı yatırımları ülkelerine çektikleri görülmektedir (Akman, 1988: 28). Kurumların yapısı da yatırımları etkilemektedir. Kurumsal yapısının kaliteli ve düzenli işleyişi işlem maliyetlerini düşürerek yatırımları artırır (Daniele ve Marani, 2006: 17). Yine demokratikleşme unsuru da yabancı yatırımlar için önemli diğer bir unsurdur (Asiedu ve Lien, 2011; Paniagua - Sapena, 2014). Ülkelerin alt yapı koşullarının iyi olması yabancı yatırımların ülkeye gelmesindeki diğer bir etkendir. Şöyle ki, deniz, hava ve kara ulaşımının iyi olması ticaret ağının genişletilmesine imkân vermekte ve maliyetleri düşürmektedir (Uçar ve Arslan, 2017:8). Makroekonomik bir değişken olan enflasyon oranları da uluslararası yatırımları etkileyebilmektedir. Enflasyon oranı yüksek olan ülkelerde, yatırımcılar belirsizliklerin olduğunu düşünerek yatırımlarını kısıtlamayı tercih etmektedir. Bu ise doğrudan yabancı yatırımların azalmasına neden olmaktadır (Şahinoğlu ve Mortazavimoulou, 2017: 149). Doğrudan yabancı yatırımları sayesinde dışa bağımlı olarak yaşayan ülkelerin bu bağımlılıktan kurtulması ya da bağımlılı̆̆ın azaltılması mümkün olmaktadır.

\section{DOĞRUDAN YABANCI YATIRIMLARIN YATIRIM YAPILAN ÜLKELERE ETKILERİ}

Uluslararası yatırımlar doğrudan yabancı yatırımlar (DYY) ve finansal yatırımlar olarak iki temel gruba ayrılmaktadır. DYY'ler üretim ve hizmet sektörlerine daha uzun süreli yatırımlar olarak değerlendirilmektedirler. Finansal yatırımlar ise genelde daha kısa süreli yatırımlar olarak kabul edilir. Bu yatırımlar o ülkede kazanma potansiyeli azalınca, kur riski artınca veya diğer sebeplerden dolayı bir ülkeyi hızla terk edebilirler. Örneğin yıllardır İstanbul Borsasında \%60-70 oranında yabancı payı varken 2020 yılının temmuz ayında yabancı payı 16 seneden sonra \%50'nin altına düşmüştür. 
Yabancı sermayenin DYY için bir ülkeye gelmesi için araştırdığı çeşitli faktörler bulunmaktadır. Bunlar içinde döviz kurundaki oynaklık, hukuki altyapı, sağlanan vergi avantajları, sağlanan diğer olanaklar, işgücü niteliği, iç piyasanın büyüklüğü, lojistik maliyetleri, komşu ülkelerle ilişkiler, ülkenin kredi notu ve CDS (Kredi Temerrüt Takası) primi yer almaktadır. Finansal yatırımlar da yukarıdaki kriterlere baktığı gibi hisse senedi piyasasında potansiyel kazanç ve tekrar kendi para birimine dönüş yaparken alacağı kur riski, eğer devlet tahvili gibi faizli ürünlere yatırım yapacaksa da kendi ülkesindeki faiz ile gittiği ülkedeki faiz farkının cazibesi ile kur riski arasındaki ilişki yatııım kararlarını şekillendirir. Doğrudan yabancı yatırımları etkileyen faktörlerin durumlarına ilişskin yapılan çalışmalarda varılan sonuç genellikle ülkelerin birbirlerinden farklılık gösterdiği yönündedir (Arık vd., 2013: 101).

Büyüme ve kalkınma seviyesini artırmak isteyen gelişmekte olan ülkelerin en büyük sıkıntılarından birisi kaynakların yetersiz oluşudur. Bu nedenle de gelişmekte olan ülkeler için yabancı sermaye yatırımları oldukça önemlidir. Gelişmiş ve gelişmekte olan ülkelerin aralarındaki farkın kapatılması adına alt yapının, ulaşımın, iletişim ağının, teknolojinin, eğitimin ve sanayinin güçlendirilmesi gerekmektedir. Bu durum ise yatırımların ülkeye çekilmesini zorunlu hale getirmektedir. Böylece gelişmekte olan ülkeler büyümelerini gerçekleştirebilir. Yabancı sermaye yatırımlarının ülkeye çekilmesinde birçok makroekonomik gösterge önem arz etmektedir. Özellikle yabancı sermaye çeşitlerinden birisi olan doğrudan yabancı yatırımlar gelişmekte olan ülkeler için dolaylı yabancı yatırımlara nazaran daha çok tercih edilmektedir. Bunun nedeni ise doğrudan yabancı yatırımların ülkelere sağladıkları finansmanları ve birçok teknolojiyi ülkeye getirerek hem ülkenin kalkınmasına hem de büyümenin sağlanmasında daha çok katkısının bulunması ve daha istikrarlı olmasındandır. Diğer açıdan özellikle kısa vadeli yabancı fonlar, spekülatif nitelikli olmaları ve oynaklıklarının yüksek oluşu nedeniyle, olumsuz beklentilerin artı̆̆ dönemlerde hızla ülkeyi terk etmekte ve krizleri etkileyen bir unsur olarak ortaya çıkabilmektedir. Bu durum büyümeyi ve dolayısıyla iktisadi kalkınmayı olumsuz olarak etkilemektedir (Kar ve Tatlısöz, 2008: 436-458).

Küreselleşme eğilimlerinin hızla arttığı ve ülkelerin giderek birbirleriyle daha çok entegrasyon içinde olmaları rekabetin artmasına ve ülke stratejilerinin sürekli değişmesine neden olmaktadır. Bu durum ticaretin her geçen gün hızla artmasına ve ticaret politikalarının uluslararası yatırımları ülkeye çekecek bir biçimde düzenlenmesini gerektirmektedir. Politikaların ticareti artırıcı yönde belirlenmesi ülkeye girecek olan doğrudan yabancı yatırımların artmasını sağlayacaktır (Küçükahmetoğlu ve Varol, 2018: 119).

Ülkelerin ekonomik ve siyasi istikrarları yatırımların ülkeye yapılmasında önemlidir. Hatta buna ilaveten ülkelerin uyguladıkları dış ticaret politikaları, vergi oranları, diğer ülkelerle olan bağlantıları çok uluslu şirketlerin yatırım yapma kararlarında etkilidir. Çok uluslu şirketleri ülkelerine çekmek isteyen birçok gelişmekte olan ülke vergi oranlarını düşürmekte, dış ticaretin önündeki engelleri kaldırmaktadır. Özelleştirme politikaları sayesinde de doğrudan yabancı yatırımlar ülkelere önemli kazançlar sağlamıştır. Şöyle ki, girişimcilerin ülkeye girişi hızlanmış, getirdikleri dövizlerle beraber ödemeler dengesinin finansmanına katkı sağlamışlardır. Yabancı yatırımlar sebebiyle ulusal ve uluslararası ekonomik ve politik ilişkiler geliştirilecek, hükümetin gelirleri artırılacak ve mevcut sermaye daha iyi kullanılmak suretiyle kârlılık artırılacaktır. Ülkeye çekilen yabancı yatırımlar sayesinde teknoloji girişinin sağlanması rekabeti artırarak ihracatta da artış meydana getirebilir.

Ülkeler arasında kurulan ekonomik entegrasyonlar, doğrudan yabancı yatırımlar açısından önemlidir. Ekonomik entegrasyonda, birlik üyesi ülkeler arasında ticaretin önündeki engellerin kaldırılması piyasa hacminin genişlemesine neden olarak yabancı sermaye yatırımların bölgeye girmesini sağlamaktadır. $\mathrm{Bu}$ nedenle entegrasyon içinde bulunmak önemlidir (Çeştepe ve Mistaçoğlu, 2010: 94). Özellikle gelişmekte olan ülkelerin entegrasyon içinde olmaları yabancı sermayeden daha yüksek bir pay hakkı elde etmesine neden olabilir (Candemir, 2009: 668). Gelişmekte olan ülkeler eğer daha fazla doğrudan yabancı yatırımları çekmek istiyorlarsa makroekonomik performanslarını iyileştirmeli, demokratikleşme süreçlerine önem göstererek hukukun üstünlüğ̈n̈ü sağlamalıdırlar (Ağır ve Rutbil, 2019: 484).

24 Ocak 1980 kararları ile ekonomide liberalleşme sürecine geçilmesi hem Türkiye'nin dış ticaretini hem de uluslararası yabancı yatırımların Türkiye'ye girişini etkilemiştir. Küresel salgın sürecinde hanehalkı harcamaları da etkilenmiştir. Üretim ve tüketimin süreçlerden etkilenmesi GSMH ve GSYIH oranlarını da değiştirmiştir. Merkez Bankalarının ve Hükümetlerin salgın sürecindeki olumsuzlukları azaltmak adına bu süreçte çeşitli tedbirler alması doğrudan yatırımları etkilemiştir. Çünkü süreç yatırımcıların güvenini sarsmış ve istikrarsızlıkların artığı bu dönemde yatırımlar oldukça azalmışıı. Salgın, ülkelerdeki istihdam oranlarını da hızlı bir biçimde etkilemiş ve bu süreçte cok sayıda insanın işsiz kalmasına ve bazı üretim yerlerinin kepenk 
kapatmasına dolayısıyla ekonomideki Keynes'yen bakış açısıyla gelir harcama döngüsünün kısır bir noktaya gelmesine sebebiyet vermiştir. Çünkü Keynes'inde belirttiği gibi her ekonomik aktörün harcaması başka bir ekonomik aktörün geliridir. Doğrudan yabancı yatırımlar kısaca, ülkenin sahip olduğu istihdam, ihracat, ödemeler dengesi ve enflasyon gibi ekonomik göstergeleri etkilemektedir (Koçtürk ve Eker, 2012: 35). Bu olumlu katkılarından dolayı ülkeler Çok Uluslu Şirketleri (ÇUŞ) ülkelerine çekebilmek adına yarış içerisindedirler. Ülkelere gelen yabancı yatırımların olumlu etkileri yanında olumsuz etkileri de olabilir. Olumsuz etkiler ise ülkeler açısından istikrarsızlıkların oluşmasına neden olabilir. Şöyle ki; yabancı sermayenin durumundaki değişmeler daha kısa vadeli ve spekülatif nitelikler taşıması buna ilaveten istediği zamanda ülkeden ayrılması gibi (Berksoy ve Saltoğlu, 1998: 3) nedenlerden ötürü ülke ekonomilerinin döviz piyasaları, ödemeler dengesi hesapları, finansal piyasaları gibi birçok makroekonomik parametresi bu değişimden hızlıca etkilenmektedir. Yaratacağı olumsuz etkiler ülkelerin daha yüksek maliyetlere katlanmasına neden olacaktır (Oktar, 1995: 5-12). Doğrudan yabanc1 yatırımların kısa vade ve uzun vadede ödemeler bilançosu üzerindeki etkisi açısından uzun dönemde pozitif bir etki için döviz kazandırıcı ithalat ikamesi ve ihracat gelirlerinin, yabancı üretim faktörleri payı, girdi ithalatı için yapılan döviz transferleri ve döviz olarak ev sahibi ülkeye gelen sermaye ile yatırımın amortisman değeri arasındaki farkının pozitif olması gerekmektedir (Alpar, 1978: 80).

\section{ARAŞTIRMANIN AMACI}

Bu çalışmada küresel salgın Covid-19 nedeniyle geliş̧mekte olan ülkelerin yatırım ve sermaye piyasalarındaki durumu ele alınmıştır. Çalışmanın bu alanlarda araşııma yapan diğer çalışmalar içinde kaynak oluşturacağı düşünülmektedir. Covid-19 ülkelerin hem dış ticaret politikalarını hem de finans akışlarını etkilemiş̧ir. Bu husus her ülkenin salgının etkisinden daha az etkilenmek adına önlemler almasına sebebiyet vermiştir.

\section{A. Yöntem}

Araştırmada yöntem olarak Covid-19 süresince gelişmekte olan ülkelerin doğrudan yabancı yatırımlarındaki ve sermaye piyasalarına olan fon akışlarındaki değişiklikler baz alınmıştır. Çalışma halen devam etmekte olan pandeminin başlangıcından Ekim-2021'ye kadar olan süreci incelemektedir. O tarihe kadar olan nicel veriler baz alınmış, bazıları yazarlar tarafından hesaplandıktan sonra gelişmiş ve gelişmekte olan ülkeler arasından rasgele örnekleme yaparak borsalar, kur hareketleri ve doğrudan yabancı yatırımlardaki benzer ve zıt hareketler kıyaslanmıştır.

\section{i. Covid-19'un Dünya Borsaları Üzerindeki Etkileri}

Pandeminin ülke ekonomileri üzerindeki etkileri hem arz hem de talep yönlü olarak kendini göstermektedir. Dolayısıyla sürecin kontrol altına alınmasına yönelik kısıtlamalar ve belirsizliklerin yol açttğı endişeler çeşitli sektörler üzerinde dolaylı ve dolaysız etkilerin oluşmasına neden olmuştur. Gerek çalışanlar, tüketiciler gereksede yatırımcılar ve yerel yetkililerin bu güvensiz ortamdaki yön belirsizliği piyasalarda dalgalanmalara neden olmuştur (Türk vd., 2020:626). Pandemi esnasında virüsün ekonomi ve finansal piyasalar üzerinde etkisini araştıran yayınlardan Türkiye için yapılan bir çalışma (Öztürk vd.,2020) Korona vakalarındaki \%10'luk artışın BIST100 endeksini \%1 düşürdüğü sonucuna ulaşmışlardır. Virüsün yaygınlaşmaya başlamasıyla hemen hemen bütün sektörlerin olumsuz etkileneceğini bekleyen yatırımcılar bütün borsalarda satışa geçtiler. Düşüş yönünde bütün borsalar benzerlik gösterse de çıkış yönünde ayrışmalar çok belirgin olarak görülmektedir. Borsaların hareketlerini incelemek için beş gelişmiş ülke borsası ile iki gelişmekte olan ülke borsası incelemeye alınmıştır. 


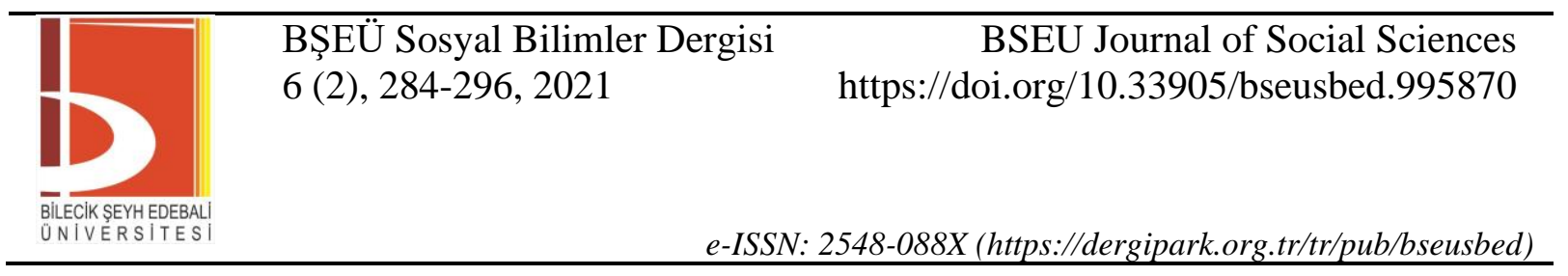

Tablo 1. Ülke Borsalarının Karşılaştırılması

\begin{tabular}{|c|c|c|c|c|c|c|c|c|c|}
\hline & \begin{tabular}{|l|}
2019 \\
Sonu
\end{tabular} & \begin{tabular}{|l|}
2020 \\
En Düşük \\
\end{tabular} & \begin{tabular}{|l|}
$\begin{array}{c}\text { \%Değişim } \\
\text { 2019-2020 }\end{array}$ \\
\end{tabular} & \begin{tabular}{|l}
2020 \\
En Yüksek
\end{tabular} & \begin{tabular}{|l|} 
\%Değişim \\
2019-2020
\end{tabular} & \begin{tabular}{|l|}
2020 \\
Sonu
\end{tabular} & $\begin{array}{l}\text { \%Değişim } \\
\text { 2019-2020 }\end{array}$ & \begin{tabular}{|l|}
$\begin{array}{l}\text { 29.10.2021 } \\
\text { Kapanış }\end{array}$ \\
\end{tabular} & \%Değişim \\
\hline SP500 & 3231 & 2237 & $-31 \%$ & 3580 & $11 \%$ & 3756 & $16 \%$ & 4605 & $23 \%$ \\
\hline Dax30 & 13249 & 8442 & $-36 \%$ & 13789 & $4 \%$ & 13719 & $4 \%$ & 15689 & $14 \%$ \\
\hline Nikkei250 & 23657 & 16553 & $-30 \%$ & 24084 & $2 \%$ & 27444 & $16 \%$ & 28893 & $5 \%$ \\
\hline FTSE100 & 7542 & 4899 & $-35 \%$ & 7690 & $2 \%$ & 6461 & $-14 \%$ & 7238 & $12 \%$ \\
\hline CAC40 & 5978 & 3755 & $-37 \%$ & 6111 & $2 \%$ & 5551 & $-7 \%$ & 6830 & $23 \%$ \\
\hline Bovespa & 115645 & 63570 & $-45 \%$ & 119527 & $3 \%$ & 119017 & $3 \%$ & 103501 & $-13 \%$ \\
\hline BIST100 & 1144 & 819 & $-28 \%$ & 1484 & $30 \%$ & 1477 & $29 \%$ & 1522 & $3 \%$ \\
\hline
\end{tabular}

Kaynak: www.macrotrends.net. \%değişimler yazarlar tarafından hesaplanmıştır.

2020 yılında gelişmiş ülkelerin borsaları \%30'dan fazla bir düşüş göstermiştir. Fransız CAC40 borsa endeksi \%37 ile en büyük düşüşü göstermiş̧ir. Gelişmekte olan ülkelerden Brezilya ve Türkiye'de ise çarpıcı bir fark görülmektedir. Bovespa endeksi -\%45 ile tablodaki en düşük değerdir. Brezilya'da vaka sayısının çok olması bunda etkili olmuştur demek kesin olarak mümkün değildir zira Bovespa endeksinin de en düşük olduğu gün 23 Mart'tır. Gelişmiş ülkelerde en düşük seviyenin görüldüğü günler de 18 Mart ile 23 Mart 2020 arasındadır. Bu düşüşte BIST100 endeksi Bovespa'dan pozitif ayrışmış görünmektedir.

$\mathrm{Bu}$ araştırmanın veri olarak baz aldığ son gün 29 Ekim 2021'dir. Buradaki farklılıklar daha çarpıcıdır. 2020 sonu itibariyle sadece FTSE100 ve CAC40 endeksleri 2019 yılının altında kapatmıştır. Ekim 2021 kapanışları ise 2020 yılına göre SP500 ve CAC40 endekslerinde \%23'lük bir artış göstermektedir. 2020 yılına göre ekside kalan tek endeks Bovespa olmuştur. Tek tek ülkelerdeki farklı sonuçları incelemek ayrı bir araştırmanın konusu olacaktır. ABD'nin SP500 endeksi en hızlı olarak eksi bölgeden çıkmış bir borsa olarak gözümüze çarpmaktadır. Türk borsası ise zararlarını telafi etmiş durumdadır. SP500 endeksinin çeşitli araştırmalara konu olabilecek bir davranış gösterdiğini söyleyebiliriz. Son iki büyük düşüşü ele alırsak karşımıza bu düşüşten farklı sonuçlar çıkmaktadır. 2001 yılında SP500 endeksinin en yüksek seviyeden en düşük seviyeye düş̧mesi 353 gün sürmüş, maksimum düşüş $\% 49$ civarında olmuştur. Tekrar bir önceki en yüksek değerini geçmesi ise 2269 gün almıştır. 2008 yılında ise en yüksek değerden en düşüğe inmesi 294 gün sürmüş, düşüş $\% 57$ olmuştur. Yeni bir önceki en yüksek değerine ulaşması ise 1702 gün sürmüştür. Covid-19 krizinde ise en yüksek seviyeden en düşüğe inişi 22 gün sürmüş, tekrar en yükseğe ulaşması ise sadece 106 gün sürmüştür. Pandemi döneminde SP500 şirketlerinin çoğunun satışları ve karları düşmüşken endeksin bu kısa sürede en yükseklere ulaşmasının nedenleri arasında $\mathrm{ABD}$ hükümetinin yaptığı parasal gevşeme ve faizlerin çok düşük olmasının etkisi olmuştur.

\section{ii. Uluslararası Yatırımlar ve Kurlarda Değisşim}

Cari açık ülkelerin önemli problemlerinden birisidir. Türkiye gibi gelişmekte olan bir ülke için cari açık sorununun çözümlerinden birisi olarak bu açığın finansmanı için doğrudan yabancı yatırımların ülkeye çekilmesine çalışılmaktadır. İthalatın ihracattan fazla olması dolayısıyla oluşan dış ticaret açığı, yatırımcıların ülkeye yatırım yapıp yapmama konusunda tereddütlerini artırmaktadır. Türkiye'de yurtiçi tasarruf miktarları istenilen seviyelerde değildir. Cari açık hesaplarının resmi rezervler hesabı ile değil de sermaye ve finans hesabı ile kapatılmaya çalışılması sermaye ve finans hesabının da istikrarlı olmasını gerektirmektedir. Bu nedenle de yabancı sermaye yatırımlarının özellikle doğrudan yabancı yatırımların ülkeye çekilmesi amaçlanmaktadır. Ülkeye giren doğrudan yabancı yatırımların birçok olumlu etkiyi yaratacağı düşünülmektedir. Şöyleki; doğrudan yabancı yatırımlar ülke içinde istihdam olanaklarının artırılmasında, verimlilik artışının sağlanmasında, nitelikli kalifiye işçilerin yetiştirilmesinde, teknoloji ve bilgi ağının güçlendirilmesinde, ihracat seviyesinin artırılmasında önem arz etmektedir.

Covid-19 salgını dünya piyasalarını büyük ölçüde etkilemiştir. $\mathrm{Bu}$ etkileyiş özellikle sermaye piyasalarında gelişmekte olan ülkelerin ekonomik dengelerinin değişmesine sebebiyet vermiştir. Sermaye 


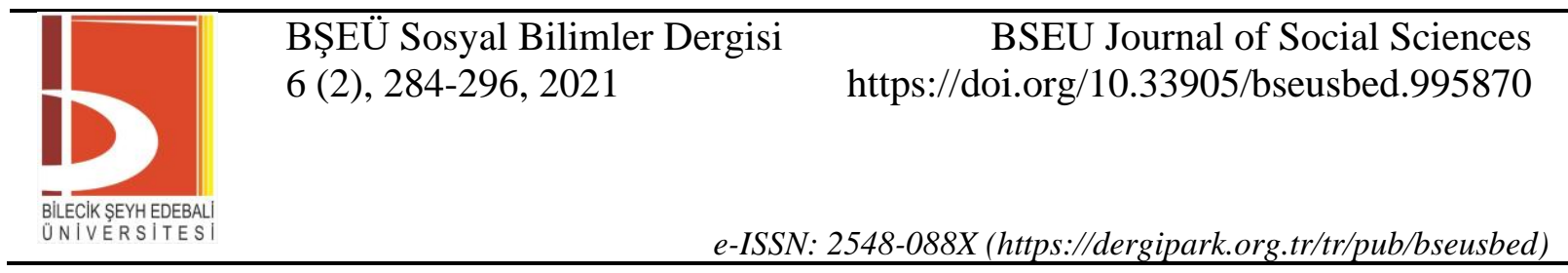

girişlerinin çok fazla olmadığı gelişmekte olan ülkelerde bu salgın nedeniyle yabancı sermaye girişleri durmuş buna ilaveten sermaye çıkışları artmıştır (Durmuş ve Şahin, 2020: 927). Bu durum ödemeler dengesi açıkları sorunu yaşayan ülkelerin dış ticaret bilançolarını etkileyerek ihracatın azalmasına neden olmuştur. Dünya da hammadde ve petrol fiyatlarındaki sert düşüşler dalgalanmaları artırmıştır. Dolayısıyla finansal piyasalarda hisse senetlerinde değer düşüşüne, borsalardan kaçışa neden olmuştur. Finansal piyasaları etkileyen diğer bir durumda dolarizasyonun yarattığı etkidir. Ülkelerin para birimleri dolar karşısında değer kaybetmiştir. Ortaya çıkan negatif etki ise altın ve ABD tahvillerine yönelimi artırmıştır (Yorulmaz ve Kaptan, 2020: 24).

Borsa endekslerinden sonra kurlara bakıldığında genel beklentilerin gerçekleşmiş olduğunu söyleyebiliriz. Para ve sermaye piyasaları kriz zamanında riskli bölgelerden risksiz bölgelere kayar. Bunun temel nedeni gelişmekte olan bir ülkenin hisse senedine veya tahviline yatırım yapılınca aynı zamanda bir kur riskinin de üstlenildiği gerçeğidir. Dünya borsaları benzer düşüşler gösterse de döviz kurları gelişmekte olan ülkelerde çok daha volatildir. Aşağıdaki tablo bu durumu net olarak ortaya koymaktadır. Farklı bölgelerde olan ve farklı ekonomik problemlere sahip Rusya, Brezilya ve Türkiye'nin kur hareketleri sert olmuştur.

Tablo 2. 2019-2020 Eylül Gelişmiş ve Gelişmekte Olan Ülkelerdeki Kur Hareketleri

\begin{tabular}{|c|c|c|c|c|c|c|c|}
\hline & $\begin{array}{l}2019 \\
\text { Sonu }\end{array}$ & $\begin{array}{l}2020 \\
\text { En Düşük }\end{array}$ & \%Değişim & $\begin{array}{l}2020 \\
\text { En Yüksek }\end{array}$ & \%Değişim & 29.10.2021 & $\begin{array}{l}\text { \%Değişim } \\
\text { 2019-2021 }\end{array}$ \\
\hline EURUSD & 1,1222 & 1,0691 & $-5 \%$ & 1,1931 & $6 \%$ & 1,1561 & $3 \%$ \\
\hline USDJPY & 108,62 & 102,35 & $-6 \%$ & 112,08 & $3 \%$ & 114,00 & $5 \%$ \\
\hline GBPUSD & 1,3250 & 1,1485 & $-13 \%$ & 1,3882 & $5 \%$ & 1,3691 & $3 \%$ \\
\hline USDRUB & 61,96 & 61,025 & $-2 \%$ & 80,85 & $30 \%$ & 70,95 & $15 \%$ \\
\hline USDTRY & 5,95 & 5,86 & $-2 \%$ & 7,8 & $31 \%$ & 9,6030 & $61 \%$ \\
\hline USDBRL & 4,02 & 4,02 & $0 \%$ & 5,89 & $47 \%$ & 5,6372 & $40 \%$ \\
\hline
\end{tabular}

Kaynak: www.tradingview.com, \% değişimler yazarlar tarafından hesaplanılmıştır.

2019-Ekim 2021 arası Euro, sterlin ve yen'deki hareketler sterlin hariç \%3 ile \%5 civarında oluşmuştur. Ruble $\% 15$ değer kaybederken real ise $\% 40$ değer kaybetmiştir. Türk lirası ise negatif ayrışıp \%61 değer kaybetmiştir. Bir örnek verecek olursak Brezilya Bovespa endeksine 2020 başında yatırım yapan bir ABD’li yatırımcı $\$ 100,000$ 'sını 4,02'den real'e çevirip hisse senedi almış olacaktı. 29 Ekim 2021 'e kadar beklemiş olsaydı, portföyünün değeri $\$ 63.823$ olacaktı. Diğer bir değişle realize olmamış zararı $\% 36,2$ olacaktı. Türkiye için hesaplarsak $\$ 100,000$ 'i 5,95'ten çevirince elinde 595.000TL olacaktı. 29 Ekim'de ise portföyün değeri $\$ 82,433$ olacaktı. Realize edilmemiş zarar \%17,6 olacaktı. Türkiye'de kur daha değer kaybettiği halde endeksin getirisi daha yüksek olduğu için yabancı yatırımcının zararı Brezilya'ya yatırım yapana göre daha az olacaktı. Yatırımcı eğer tahvillere yatırım yapsaydı tam tersi bir durum olacaktı zira tahvil getiri farkı kur zararını azaltamayacaktı.

\section{iii. Pandeminin Doğrudan Yabancı Yatırımlar Üzerindeki Etkileri}

Yatırımcıların ülke tercihlerinin temelinde yatan kar elde etme güdüsüdür ancak karlılığın devamının sağlanması için ülkenin ekonomi politikalarının tutarlılık ve devamlılık arz etmesi gerekir (Güçlü, 2011). Pandemi nedeniyle özellikle gelişmekte olan ülkelerin ekonomik dengeleri değişmiş ve sermaye girişleri azalmış hatta yabancı sermaye girişleri neredeyse durmuştur. Tablo 3'de görüleceği üzere DYY Giriş ve Çıkışlarında 2020 y1lında önemli değişiklikler olmuştur. DYY girişlerinde Avrupa bölgesi 2020'de -\%78'lik bir düşǚş yaşamıştır. Kuzey Amerika -\%35'lik bir düşüşle Avrupa'yı takip etmiştir. Asya'da düşüş olmadığı gibi küçük bir artış gözlenmiştir. Dünya genelinde ise $-\% 42^{\prime}$ lik bir düşüş olmuştur. DYY çıkışlarında ise Avrupa neredeyse içine 


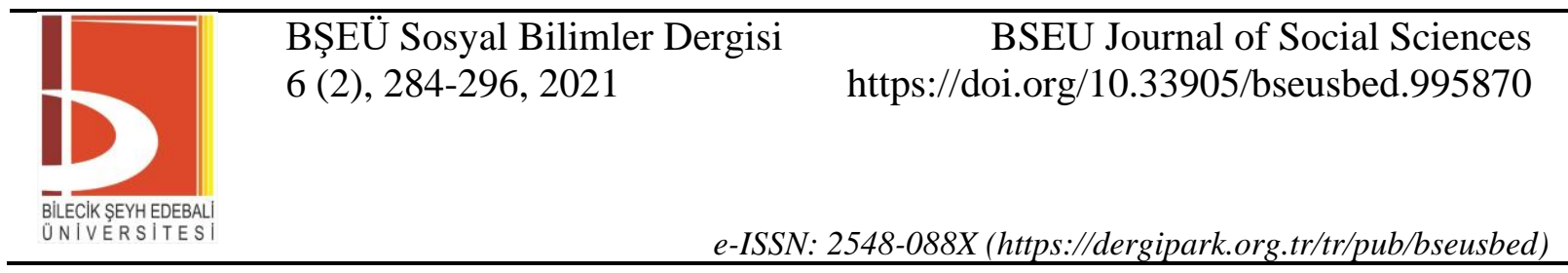

kapanmıştır diyebiliriz. Avrupa DYY çıkışları -\%79 azalmıştır. Kuzey Amerika ve Asya'daki düşüş \%15-17 bandında kalmıştır. Dünya genelinde ise düşüş -\%35 olmuştur.

Tablo 3. Doğrudan Yabancı Yatııım Girişleri-Çıkışları ve Mevcut Durum

\begin{tabular}{|l|r|r|r|r|}
\hline \multicolumn{1}{|c|}{ DYY Girişleri } & \multicolumn{4}{|c|}{ (Milyar dolar) } \\
\hline Ekonomik Bölgeler & $\mathbf{2 0 1 7}$ & $\mathbf{2 0 1 8}$ & $\mathbf{2 0 1 9}$ & $\mathbf{2 0 2 0}$ \\
\hline Dünya & $\mathbf{1 6 4 7}$ & $\mathbf{1 4 3 7}$ & $\mathbf{1 5 3 0}$ & $\mathbf{9 9 9}$ \\
\hline Gelişmiş ekonomiler & $\mathbf{8 5 8}$ & $\mathbf{6 3 3}$ & $\mathbf{7 1 8}$ & $\mathbf{2 6 9}$ \\
\hline Avrupa & 540 & 371 & 409 & 89 \\
\hline Kuzey Amerika & 318 & 262 & 309 & 180 \\
\hline Gelişmekte Olan ekonomiler & $\mathbf{7 0 1}$ & $\mathbf{6 9 9}$ & $\mathbf{6 8 5}$ & $\mathbf{7 0 6}$ \\
\hline Afrika & 40 & 45 & 47 & 40 \\
\hline Asya & 545 & 537 & 560 & 578 \\
\hline Latin Amerika ve Karayipler & 156 & 150 & 160 & 88 \\
\hline Okyanusya & $\mathbf{4 8}$ & $\mathbf{7 1}$ & $\mathbf{5 5}$ & $\mathbf{1 7 4}$ \\
\hline DYY Çıkıșları & & & & \\
\hline Dünya & $\mathbf{1 6 0 5}$ & $\mathbf{8 7 1}$ & $\mathbf{1 2 2 0}$ & $\mathbf{7 8 9}$ \\
\hline Gelişmmiş ekonomiler & 943 & 310 & 559 & 223 \\
\hline Avrupa & 539 & 447 & 387 & 81 \\
\hline Kuzey Amerika & 404 & -137 & 172 & 142 \\
\hline Gelișmekte Olan ekonomiler & 655 & 552 & 652 & 507 \\
\hline Afrika & 12 & 8 & 5 & 2 \\
\hline Asya & 607 & 542 & 600 & 509 \\
\hline Latin Amerika ve Karayipler & 36 & 2 & 47 & -4 \\
\hline Okyanusya & $\mathbf{7}$ & $\mathbf{9}$ & $\mathbf{9}$ & $\mathbf{1 0}$ \\
\hline
\end{tabular}

Kaynak: UNCTAD, FDE/MNE. (www.unctad.org/fdistatistics)

Tablo 4'e bakacak olursak Türkiye'ye gelen DYY Şubat 2020 döneminden sonra Temmuz 2020'ye kadar düşüş yaşamakta, Temmuz ve Aralık 2020 girişleri ile 2020 büyük bir kayıp vermeden tamamlanmıştır. 2019 DYY toplamı 5.878 milyon dolar iken 2020 yılında 5.791 milyon dolar olmuştur. Sadece $\% 1,5^{\prime}$ luk bir düşüş yaşanmıştır. 2021 Ağustos sonuna kadar ise 3.441 milyon dolarlık yatırım olmuştur. 


\begin{tabular}{|c|c|c|}
\hline & $\begin{array}{l}\text { BŞEÜ Sosyal Bilimler Dergisi } \\
6(2), 284-296,2021\end{array}$ & $\begin{array}{r}\text { BSEU Journal of Social Sciences } \\
\text { https://doi.org/10.33905/bseusbed.995870 }\end{array}$ \\
\hline $\begin{array}{l}\text { BILECIK SEYY EDEBALL } \\
N \text { IVERSITES }\end{array}$ & $e-I S S \Lambda$ & 548-088X (https://dergipark.org.tr/tr/pub/bseusbed) \\
\hline
\end{tabular}

Tablo 4. Son Bir Senede Türkiye’ye Gelen Doğrudan Yabancı Yatırımlar

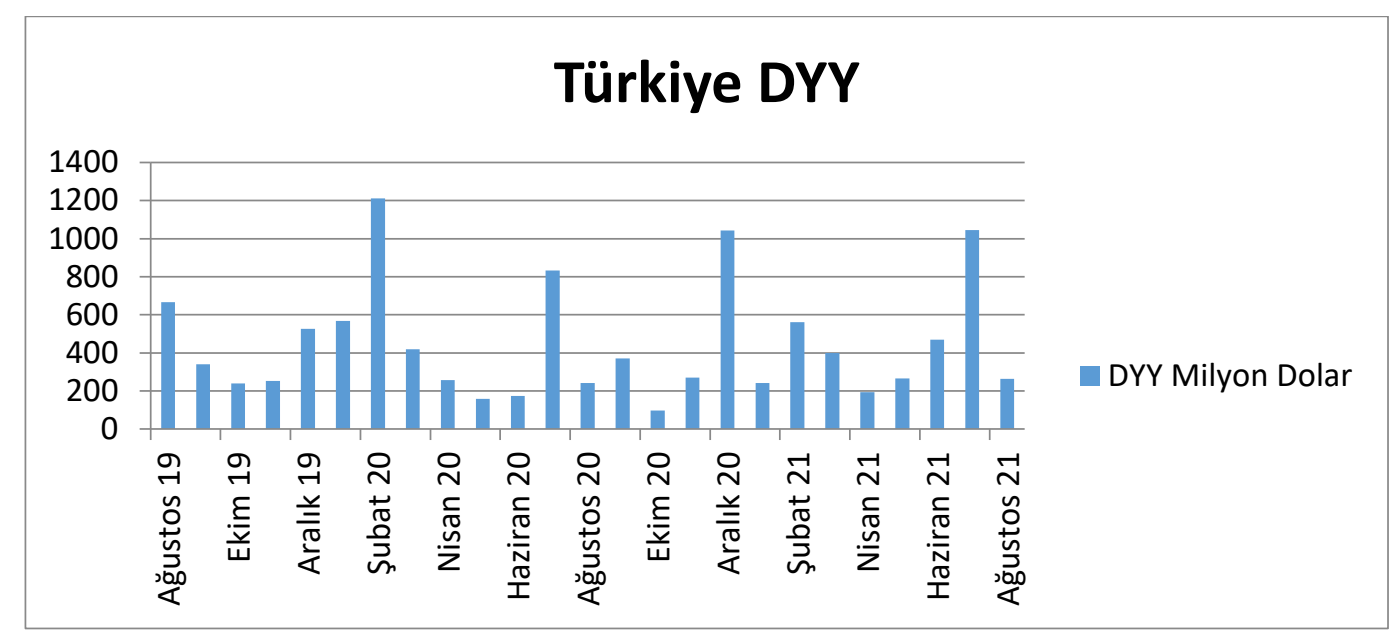

Kaynak: https://tradingeconomics.com/turkey/foreign-direct-investment, TCMB

Aşağıdaki tabloda BRICS üyesi olan ve Türkiye ile ekonomisi karşılaştırılan Brezilya'nın son bir seneki DYY değişimleri gözlenmektedir. Türkiye'nin aksine Brezilya'da DYY 2019'da toplam 69.175 milyar dolarken 2020'de 44.662 milyon dolara düşmüştür. \%35,4'lük bu düşüş 2021 y1lında da tam toparlanacak gibi gözükmemektedir. 2021 Ağustos sonuna kadar DYY 36.245 milyon dolar olmuştur.

Tablo 5. Son Bir Senede Brezilya'ya Gelen Doğrudan Yabancı Yatırımlar

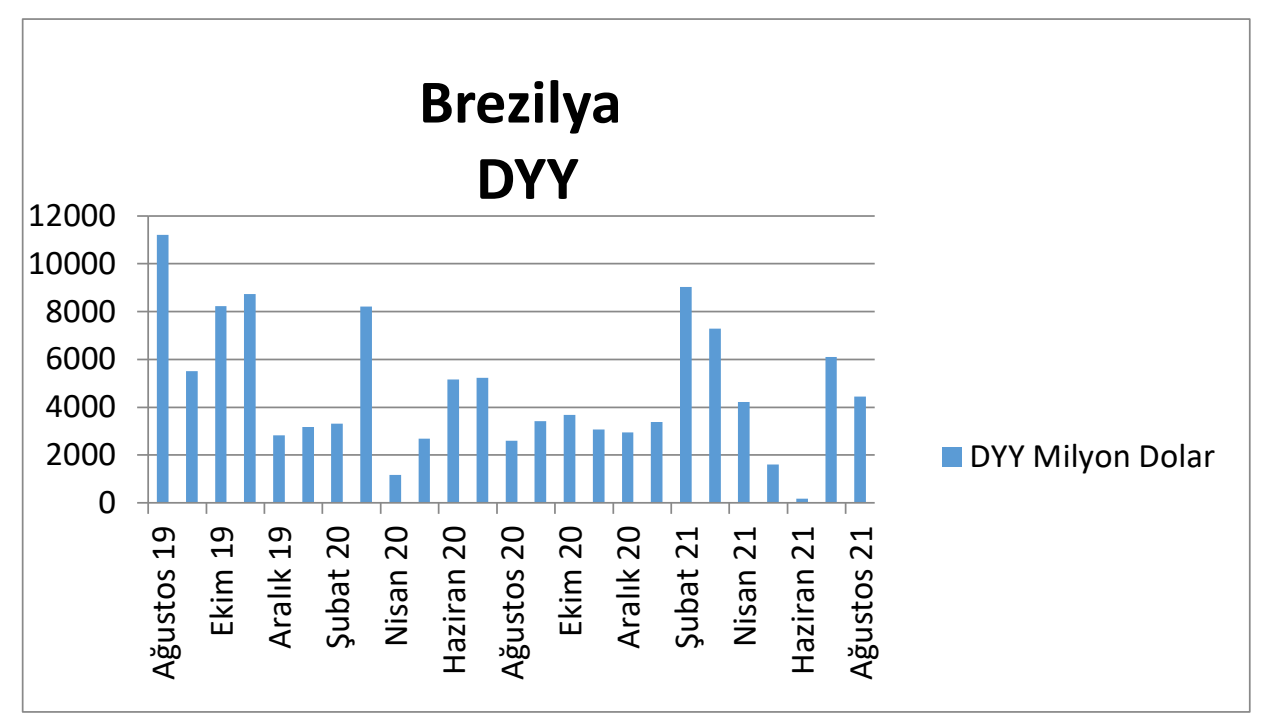

Kaynak: https://tradingeconomics.com/turkey/foreign-direct-investment, Brezilya Merkez Bankas1

Son olarak gelişmiş ülke olarak Almanya'nın rakamlarına bakacak olursak pandemiden DYY yönünde olumlu etkilendiğini görmekteyiz. 2019 DYY toplamı 60.471 milyon euro iken 2020'de 97.213 milyon euroya çıkmıştır. Bu \%60,8'lik bir artışa denk gelmektedir. 2020 yılında gelişmiş bir ülke olarak DYY'den çok olumlu etkilendiği net olarak görülmektedir. 2021 yılında ise aynı olumluluk yerini oldukça az bir DYY seviyesine bırakmıştır. 2021 Ağustos ayına kadar toplam DYY yalnızca 26.743 milyon euro olmuştur. 


\begin{tabular}{|c|c|c|}
\hline & $\begin{array}{l}\text { BŞEÜ Sosyal Bilimler Dergisi } \\
6(2), 284-296,2021\end{array}$ & $\begin{array}{r}\text { BSEU Journal of Social Sciences } \\
\text { https://doi.org/10.33905/bseusbed.995870 }\end{array}$ \\
\hline $\begin{array}{l}\text { BILECIK SEYY EDEBALL } \\
N \text { IVERSITES }\end{array}$ & $e-I S S \Lambda$ & 548-088X (https://dergipark.org.tr/tr/pub/bseusbed) \\
\hline
\end{tabular}

Tablo 6. Son Bir Senede Almanya'ya Gelen Doğrudan Yabancı Yatırımlar

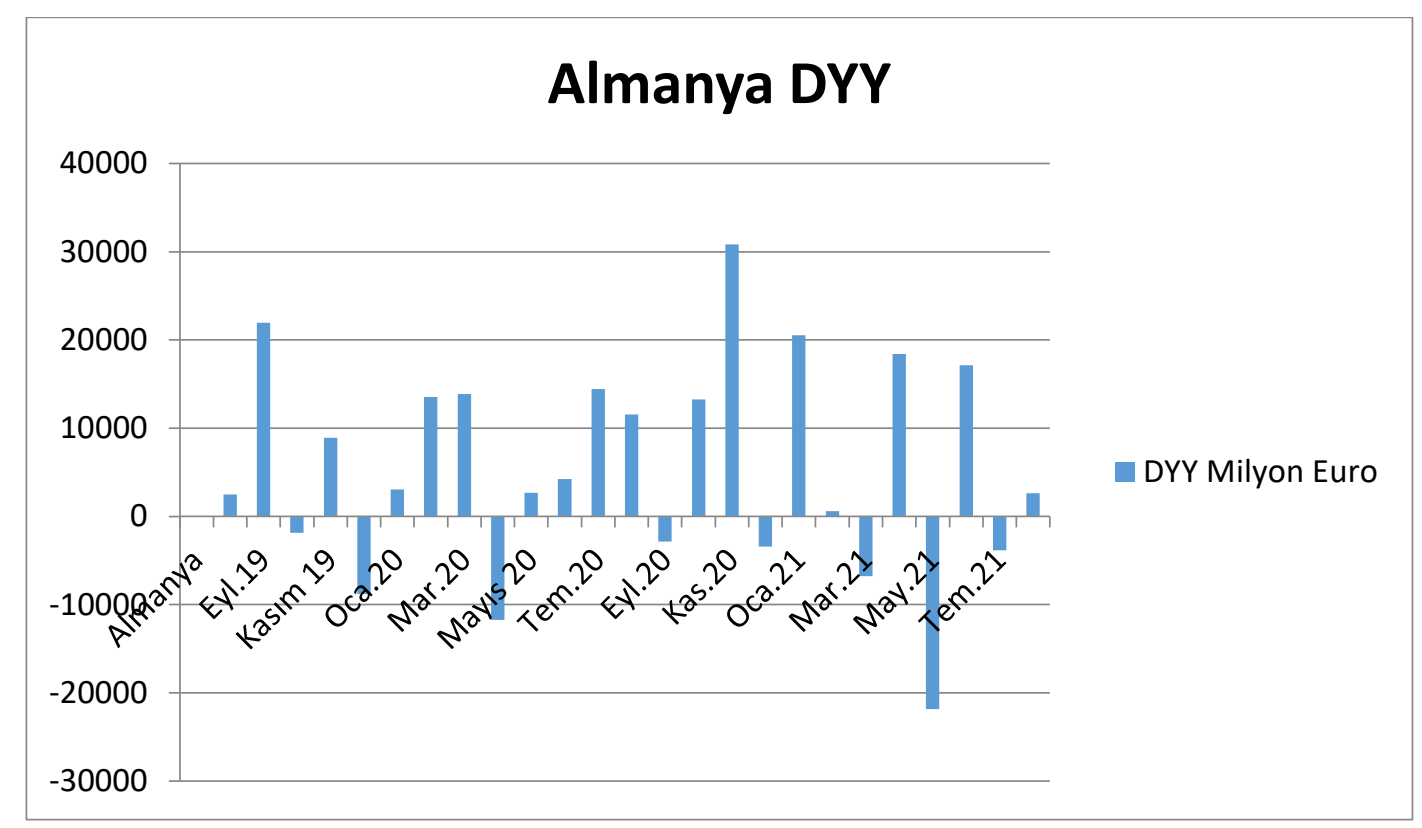

Kaynak: https://tradingeconomics.com/turkey/foreign-direct-investment, Alman Merkez Bankas1

Tablolara farklı bir açıdan bakacak olursak durum tespitine daha katkısı olabilir. Bunun için pandemi dönemi öncesi olan Ağustos 2019-Şubat 2020 dönemindeki aylık DYY ortalamasını bulup Mart-2020 ile Temmuz-2020 arasındaki ortalama DYY ile karşılaştırıldı. Türkiye'nin ilk dönem ortalaması 543 milyon dolar iken ikinci kısımda 368 milyon dolara düşmüştür. Bu \%32,2' lik bir düşüşe karşılık gelmektedir. Brezilya'nın ilk dönem ortalaması 5.916 milyon dolarken 3.506 milyon dolara düşmüşsür. $\mathrm{Bu} \%$ 40,7'lik düşüş Türkiye'den büyüktür. Almanya ise iki negatif ay yaşamasına rağmen ilk dönemde 5.611 milyon euro olan DYY ikinci dönemde 4.683 milyon euro'ya inmiş̧tir. Bu düşüş ise sadece \%16,5'lık bir düşüşe karş1 gelmektedir.

\section{iv. Portföy Yatırımlarındaki Değiş̧imler}

Türkiye, Brezilya ve Almanya'da portföy hareketlerini inceleyecek olursak farklı sonuçlar görmekteyiz. Portföy yatırımları hisse senedi, ortaklık paylarını kapsamaktadır. Tablo-7'de ülkeler arası farklar ve yıldan yıla farklar gözükmektedir.

Tablo 7. Türkiye, Brezilya ve Almanya'da Net Portföy Yatırımları

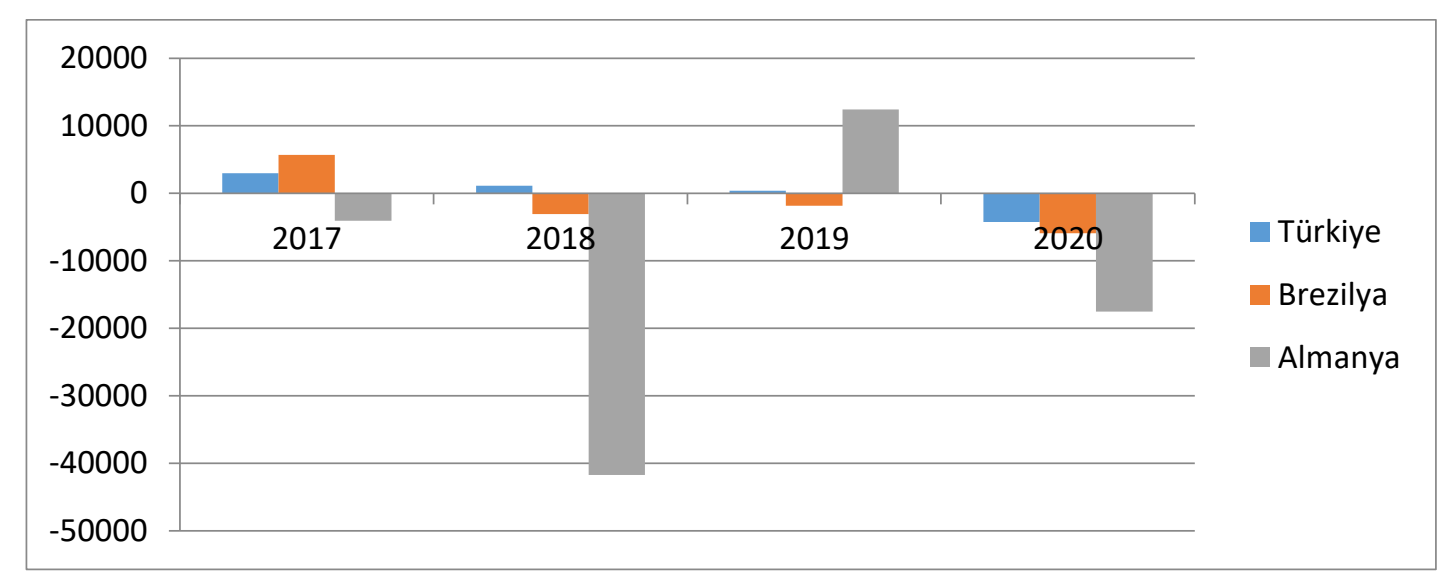

Kaynak: https://www.theglobaleconomy.com/ The Global Economy. 
Almanya net olarak yurtdışına portföy yatırımı yapmaktadır. Brezilya ise 2017 'de net portföy yatırımı aldıktan sonra dışarıya portföy çıkışı gözlenmektedir. Türkiye ise 2020'ye kadar net portföy yatırımı alırken 2020 yılında 5.926 milyon dollar portföy yatırımı yurtdışına çıkmıştır. Devlet İç Borçlanma Araçlarında (DİBS) yabancıların elindeki portföy büyüklüğü 2019 sonunda 82.736 milyon TL iken 2020 sonunda $\% 25,2$ 'lik bir düşüssle 61.860 milyon TL olmuştur. 2021 Ekim sonu itibariyle yabancı yatırımcıların DỉBS portföy değeri artmış ve 70.103 milyon TL olmuştur.

\section{SONUÇ}

Günümüzde dünyamız küresel salgın nedeniyle hızlı bir değişim sürecine girmiş bulunmaktadır. Üretim ve tüketim kalıplarının değişime uğradığı, makro ve mikro düzeyde yaşanan değişimler dolayısıyla ülkelerin ekonomik dengelerinin değiştiği bu süreç, yeni bir dünya düzeninin oluşmasına neden olmuştur. Ülkeler salgını önlemek amacıyla gerek para gerek maliye gerekse de dış ticaret politika araçlarıyla çeşitli önlemler almaya çalışsalar da içinde bulunulan durumun salgını tamamen bitirici aşı bulununcaya kadar kaos ortamını sürdüreceği düşünülmektedir. Belirsizlikler ve geleceğin öngörülememesi birçok dengenin altüst olmasına neden olmaktadır. Elbetteki her ülkenin kendine özgü yapısından dolayı alınacak önlemleri farklılıklar taşımaktadır.

Küresel salgın finansal piyasaların işleyişinde aksaklıklar yaratmış ve doğrudan yatırımların ülkeye girmesine ya da ülkeden hızlıca uzaklaşmasına neden olmuştur. Gelişmekte olan ülkeler eğer uluslararası doğrudan yatırımları çekmek istiyorsa buna uygun ekonomik ortamını oluşturmalıdır. Ülkenin içinde bulunduğu mevcut koşulları, iç talep yapısı, büyüme hızı, diğer ülkelere nazaran verimlilik seviyesi bunlara ilaveten hem siyasi hem sosyal şartları oldukça önemlidir. Eğer bir ülkede süreklilik arz eden istikrarsız durumlar söz konusu ise bu ülkeden yabancı sermayenin kaçışı da hızlı olacaktır. Faiz oranlarındaki değişimler, hisselerin borsadaki durumları yabancı yatırımcıları büyük ölçüde etkileyecektir. Küresel salgın sürecinde alınan parasal ve mali tedbirler buna ilaveten sağlık tedbirleri ülke ekonomilerinin ciddi zorlukların altına girmesine neden olmuştur.

Pandeminin rakamsal sonuçlarına bakıldığında genel sonuç olarak her ülkenin olumsuz etkilendiğini söyleyebiliriz. Örnek olarak beş gelişmiş borsayı ve iki gelişmekte olan ülke borsasına baktığımızda S\&P500(ABD), DAX30(Almanya) ve Nikkei250(Japonya) endekslerinin zararlarını kapattıkları görülmektedir. Bütün bu verilerin 1şığında gelişmekte olan ülkelerin hasar aldığı alanlar borsa endekslerinden çok kurlarda ve DYY'lerde olmuştur. Politika yapıcıları bu süreçte ülke ekonomisinin kötüye gidişini önlemeye yönelik kararlar almalı ve özellikle dış ticaret açı̆̆ı bulunan bu yüzden de doğrudan yabancı yatırımlara büyük oranda ihtiyaç duyan gelişmekte olan ülkelerin tedbirleri elden bırakmaması gerekmektedir.

\section{KAYNAKLAR}

African Union (2020). Impact Of the Coronavirüs (Covid-19) On the African Economy. [Erişim: 04.09.2021, https://au.int/sites/default/files/documents/38326-doc-covid19impactonafricaneconomy.pdf]

Ağır, H., \& Rutbil, M. (2019). Gelişmekte Olan Ülkelerde Doğrudan Yabancı Sermaye Yatırımları İle Ekonomik Büyüme İlişkisinin Ekonometrik Analizi. Kahramanmaraşs Sütçü İmam Üniversitesi Sosyal Bilimler Dergisi, 16 (2), 469-488.

Akman, A. (1988). Yabancı Sermaye Yatırım Neden ve Etkileri. İstanbul: YASED İnceleme Yarışması.

Alpar, C. (1978). Çok Uluslu Şirketler Ve Ekonomik Kalkinma. Ankara: İktisadi ve Ticari İlimler Akademisi Yayını.

Arık, Ş., Akay, B., \& Zanbak, M. (2013). Doğrudan Yabancı Yatırımları Belirleyen Faktörler: Yükselen Piyasalar Örneği. Anadolu Üniversitesi Sosyal Bilimler Dergisi, 14 (2), 97-110.

Asiedu, E., \& Lien, D. (2011). Democracy, Foreign Direct Investment and Natural Resources. Journal Of International Economics, 84 (1), 99-111.

Bayraktar, F. (2003). Dünyada ve Türkiye'de Doğrudan Yabancı Sermaye Yatırımları. Ankara: Türkiye Kalkınma Bankası A.S. Genel Araştırmalar. Basımevi.

Berksoy, T., \& Saltoğlu, B. (1998). Türkiye Ekonomisinde Sermaye Hareketleri. İstanbul: Mega Ajans 
Candemir, A. (2009). Doğrudan Yabancı Sermaye Yatırımlarını Etkileyen Faktörler. Ege Akademik Bakış Dergisi, 9 (2), 659-675.

Çeştepe, H., \& Mıstaçoğlu, T. (2010). Gelişmekte Olan Ülkelerde Doğrudan Yabancı Yatırımlar Ve Ekonomik Entegrasyon: Asean ve Mercosur Örneği. Yönetim ve Ekonomi: Celal Bayar Üniversitesi İktisadi ve İdari Bilimler Fakültesi Dergisi, 17 (2), 93-102.

Daniele, V., \& Marani, U. (2006). Do Institutions Matter For FDI? A Comparative Analysis of The MENA Countries. MPRA Paper.

Durmuş, S., \& Şahin, D. (2020). Covid-19 Küresel Salgında Dünyada Ve Türkiye'de Uygulanan Ekonomi Politikaları Üzerine Bir Değerlendirme. Turkish Studies, 15, 923-943.

Egger, P., \& Winner, H. (2005). Evidence On Corruption as An Incentive for Foreign Direct Investment. European Journal of Political Economy, 21 (4), 932-952.

Erdinç, Z., \& Aydınbaş, G. (2020). Determinant of The Factors Affecting Foreign Direct Investment (FDI): Panel Data Analysis For 11 Selected Countries. Journal of Current Researches on Business and Economics, $10(1), 1-18$.

Güçlï, Y. (2011). Yabancı Sermaye Çekimi, Yatırımların Karşılıklı Teşviki ve Korunması Anlaşmaları. [Erişim: 15.11.2021, http://www.mfa.gov.tr/yabanci-sermaye-cekimi-yatirimlarin-karsilikli-tesviki-ve-korunmasi-anlasmalari.tr.mfa]

Güney, N., \& Hopoğlu, S. (2021). Covid-19 Salgınının Uluslararası Sermaye Hareketliliği Üzerine Etkisi: Türkiye Örneği. Ekonomi Maliye İşletme Dergisi, 4 (1), 56-74.

Hıdıroğlu, D. (2020). COVID-19 Salgın Krizinde Etkin Bir Finansal Ortam Sağlama ve Yabancı Yatırım Projelerinin Teşviki: Kitle Fonlaması Uygulamaları. Social Sciences Research Journal, 9 (3), 209-216.

Kar, M., \& Tatlısöz, F. (2008). Türkiye'de Doğrudan Yabanc1 Sermaye Hareketlerini Belirleyen Faktörlerin Ekonometrik Analizi. Karamanoğlu Mehmetbey Üniversitesi Sosyal ve Ekonomik Araştırmalar Dergisi, (1), 436-458.

Koçtürk, O. M., \& Eker, M. (2012). Dünyada ve Türkiye'de Doğrudan Yabancı Sermaye Yatırımları Ve Çok Uluslu Şirketlerin Gelişimi. Tarım Ekonomisi Dergisi, 1, 35-42.

Kü̧̈ükahmetoğlu, O., \& Varol, N. (2018). The Effects of Participation in To Global Value Chains on The Countries' Economies: Panel Data Analysis. Eurasian Academy of Sciences Social Sciences, 22, 118 - 142.

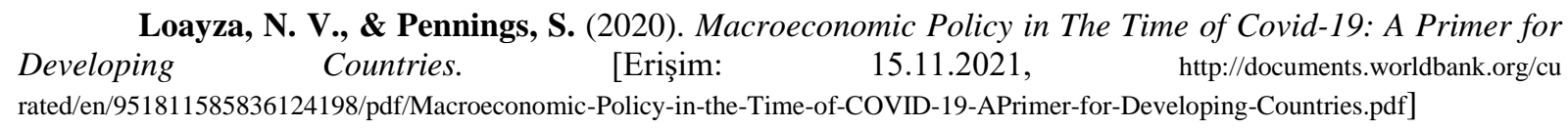

Mishra, K. M. (2020). The World after COVID-19 and its impact On Global Economy. [Erişim: 15.11.2021, https://www.econstor.eu/bitstream/10419/215931/1/MKM\%20PAPER\%20FOR\%20COVID.pdf]

Oktar, S. (1995). Uluslararası Sermaye Akışı ve Sıcak Para. Banka ve Ekonomik Yorumlar Dergisi, 32, $5-12$.

Özer, M. H., \& Kaba, G. (2020). Türkiye'de 2000-2001 Finansal Krizlerinde Uluslararası Sermaye Hareketliliğinin Rolü. Dicle Üniversitesi İktisadi ve İdari Bilimler Fakültesi Dergisi, 10 (19), 1-17.

Öztürk, Ö., Şişman, M. Y., Uslu, H., \& Çıtak, F. (2020). Effect Of COVID-19 Outbreak on Turkish Stock Market: A Sectoral-Level Analysis. Hitit University Journal of Social Sciences Institute, 13 (1), 56-68.

Paniagua, J., \& Sapena, J. (2014). Business Performance and Social Media: Love Or Hate?. Business Horizons, 57 (6), 719-728.

Sabır, H. (2001). Doğrudan Yabancı Sermaye Yatırımlarını Geliştirmekte Olan Ülkelere Yönlendirici Politikalar. Hazine Müsteşarlığı Dergisi, 26, 20- 28.

Şahinoğlu, T., \& Mortazavimoulou, M. (2017). Doğrudan Yabancı Sermaye Yatırımlarının Ekonomik, Sosyal ve Siyasi Belirleyicileri. Akademik Sosyal Araşstırmalar Dergisi, 50, 145-164. 


\section{BŞEÜ Sosyal Bilimler Dergisi}

6 (2), 284-296, 2021
BSEU Journal of Social Sciences

https://doi.org/10.33905/bseusbed.995870

Soylu, Ö. B. (2020). Türkiye Ekonomisinde COVID-19'un Sektörel Etkileri. Avrasya Sosyal ve Ekonomi Araştırmaları Dergisi, 7 (5), 169-185.

Temir, C. (2020). COVID-19'un Sermaye Piyasaları Üzerine Etkisi. İstanbul Ticaret Üniversitesi Girişimcilik Dergisi, 4 (7), 50-66.

The Global Economy (2021). About the site. [Erişim: 16.11.2021, https://www.theglobaleconomy.com]

Trading Economics (2021). Brazil Foreign Direct Investment. [Erişim: 14.11.2021, https://tradingeconomics.com/brazil/foreign-direct-investment]

Trading Economics (2020). Germany Foreign Direct Investment. [Erişim: 14.11.2021, https://tradingeconomics.com/germany/foreign-direct-investment]

Trading Economics (2020). Turkey Foreign Direct Investment. [Erişim: 15.11.2021, https://tradingeconomics.com/turkey/foreign-direct-investment]

TÜBA (Türkiye Bilimler Akademisi) (2020). Covid-19 pandemi değerlendirme raporu. [Erişim: 12.12.2020, http://www.tuba.gov.tr/files/images/2020/kovidraporu/Covid-19\%20Raporu-Final\%2B.pdf]

Türk, A., Ak Bingöl, B., \& Ak, R. (2020). Tarihsel Süreçte Yaşanan Pandemilerin Ekonomik ve Sosyal Etkileri. Gaziantep Üniervsitesi Journal of Social Sciences, 612-632.

Uçar, M., \& Arslan, S. (2017). Doğrudan Yabancı Sermaye Yatırımları. Social Sciences Studies Journal, $3(4), 1-11$.

Vial, V., \& Hanoteau, J. (2010). Corruption, Manufacturing Plant Growth, And The Asian Para-Dox: Indonesian Evidence. World Development, 38 (5), 693-705.

UNCTAD (1998). World Investment Report 1998: Trends and Determinants, [Erişim: 28.12.2020, https://unctad.org/system/files/official-document/wir1998_en.pdf]

UNCTAD (2020). World Investment Report 2020. [Erişim: 27.12.2020, https://unctad.org/en/pages/PublicationWebflyer.aspx?publicationid=2769]

Yorulmaz, R., \& Kaptan, S. (2020). Kovid-19 ile Mücadele Sürecinde Maliye Politikalarının Rolï.İçinde, İ. Demir (Ed.), Kovid-19 (Koronavirüs) salgınının ekonomik etkileri (ss. 24-30). Ankara: Yıldırım Beyazıt Üniversitesi Uluslararası İlişkiler ve Stratejik Araştırmalar (ULISA) Enstitüsü. 